DOI https://doi.org/10.30525/978-9934-588-81-5-2.5

\title{
МІКРОСКОПІЧНА БУДОВА МОЗОЛИСТОГО ТІЛА ЧОЛОВІКІВ І ЖІНОК ЗРІЛОГО ВІКУ
}

\author{
Боягіна О. Д. \\ доктор медичних наук, \\ професор кафедри анатомії людини \\ Харківський національний медичний університет \\ Жарова Н. В. \\ кандидат медичних наук, \\ дочент кафедри анатомії людини \\ Харківський національний медичний університет \\ Лебедсва А. О. \\ асистент кафедри анатомії людини \\ Харківський національний медичний університет \\ Лінник А. С.
лікар судово-медичний експерт
Харківське обласне бюро судово-медичної експертизи \\ Боягін В. P. \\ студент \\ Харківський національний медичний університет \\ м. Харків, Украӥна
}

Уся товща мозолистого тіла замкнена між двома протилежно розташованими обмежуючими гліальними оболонками, між якими є взаємно зустрічні зв'язки, що здійснюються за допомогою ламелярних відростків фібрилярних астроцитів та епендимних клітин. У результаті цього уся його товща виявляється розділеною на пошарові секції, у яких знаходиться порційна безліч нервових волокон [1]. В цьому ж порядку повинен відбуватися і розподіл у мозолистому тілі кровоносних мікросудин, оскільки відомий їх щонайтісніший зв'язок із фібрилярними астроцитами, а також відростками епендимних клітин. Слід зазначити, що в речовині головного мозку всі кровоносні судини різного діаметру суцільно знаходяться в оточенні обмежуючих гліальних оболонок таким чином, що їх стінки ніде не торкаються нервових елементів; ці гліальні оболонки відомі під назвою периваскулярних.

Мета дослідження: вивчити мікроскопічну будову мозолистого тіла.

Матеріалом дослідження служили шліфи пластинованих препаратів неосмованих та осмованих тканин мозолистого тіла людей зрілого віку. 
Результати дослідження. Встановлено, що в межах комісуральних канатиків мозолистого тіла спостерігається складно розгалужена в тривимірному просторі мережа, що складається 3 анастомозуючих між собою в певному порядку інтерстиційних щілинних прошарків, які розділяють усю однорідну масу нервових провідників на їх окремі впорядковані співмножини, серед яких виразно виділяються фасцикулярні порціони. Виходячи з уявлень про морфофункціональну систему мікроциркуляторних процесів у органах [2], можна стверджувати, що такі інтерстиційні прошарки $є$ шляхами позасудинної циркуляції рідини з розчиненими в ній поживними речовинами, що здійснюють трофіку не окремо взятих нервових волокон, а певних їх сукупностей. Отже, зазначені інтерстиційні прошарки є опосередкованим середовищем в обмінних процесах між кров'ю та нервововолокнистими порціонами, а міжтканинна рідина, що міститься в них, є фільтратом плазми крові; при чому процес іiі фільтрації здійснюється за допомогою обмінних кровоносних мікросудин через їх ендотеліальне вистилання. Цими загальними зауваженнями ми намічаємо питання, що безпосередньо належить до проблеми гематоенцефалічного бар'єру, яка у літературі абсолютно не конкретизована 3 погляду на білу речовину головного мозку.

Першочерговим завданням при вирішенні цього питання $є$ встановлення місця розташування мікросудин капілярного типу. Виходячи 3 вище поданої дефініції про просторову організацію інтерстиційних прошарків, такі мікросудини не слід шукати у безпосередньому зв'язку з нервовими волокнами; вони повинні знаходитися в межах указаних прошарків. Але у зв'язку з тим, що останні мають двомірно простягнуту форму між фасцикулярними та субфасцикулярними порціонами, а кровоносні мікросудини лінійно пролягають у їх межах, вони далеко не завжди і не скрізь виявляються. I все-таки результати наших досліджень візуально засвідчують, що місцем їх розташування $€$ міжфасцикулярні інтерстиційні прошарки.

Звернемося до розгляду того його вмісту, який розділений мережею інтерстиційного прошарку. Зрозуміло, що йдеться про провідні структурні елементи мозолистого тіла, якими є переважно мієлінізовані нервові волокна. Звісно, що через мікроскопічні розміри вони не візуалізуються на оглядових товстих епоксидних шліфах, але у своїй масі визначають тинкторіальні властивості тканини мозолистого тіла, які проявляються при забарвленні метиленовим синім. Розрізнити їх вдається тільки на тонких шліфах заздалегідь осмованих препаратів при середньому збільшенні світлового мікроскопа (об'єктив $10^{\mathrm{x}}$ ). Погляду відкривається базофільне (із деяким проявом метахромазії) поле, змережене численними, кластерно розташованими просвітними 
комірками, які помилково і можна прийняти за поперечні профілі нервових волокон. Насправді ж останні займають серед них проміжне положення, перебуваючи у щільно згрупованій спільності, у якій їх межі не розрізняються. При такому невеликому збільшенні світлового мікроскопа у цих сукупностях тільки 3 великими зусиллями вдається розрізнити окремі нервові волокна у вигляді округлих або овальних, гранично дрібних утворень із наявністю просвіту в центрі, що зобов’язано імпрегнації осмієм їх мієлінових оболонок. Чіткіше їх можна побачити на тонких епоксидних шліфах при великих збільшеннях світлового мікроскопа.

При великих збільшеннях світлового мікроскопа виявляється, що ці комірки не $є$ порожніми: кожна з них є місцем розташування окремої клітини. У випадку, коли площина шліфа (тобто зрізу) опиняється посередині комірки, у цих клітинах чітко видно ядро округлої форми, в якому конденсований хроматин у вигляді вузької смужки займає пристінне положення (тобто прилягає до ядерної мембрани), а також зосереджений у центрі ядра у вигляді ядерця. При ретельному вивченні вдається встановити, що саме тіло таких клітин цю комірку займає не повністю, а розміщується так, що між клітиною та стінкою комірки залишається вузький вільний простір (перицелюлярний); це є наслідком підвищеної гідратації міжтканинного простору, в якому знаходиться гелевидна речовина, що є ковалентними з'єднаннями глікозаміногліканів із протеїнами, які мають здатність зв'язувати певні кількості вільної води, при надлишку якої цей міжклітинний простір зазнає розширення.

Розглянемо питання про природу цих комірчасто розташованих клітин. За своєю локалізацією та деякими цитологічними ознаками ними, безумовно, будуть так звані інтерфасцикулярні олігодендроцити, які, як відомо, є найчисленнішими клітинами білої речовини головного мозку. Згідно з даними літератури найбільш характерною особливістю цих гліальних клітин $є$ наявність у їх цитоплазмі добре розвиненого ендоплазматичного ретикулуму й апарату Гольджи, що однозначно вказує на їх секреторні цитофізіологічні властивості, які пов'язані 3 продукцією необхідних речовин у процесі мієлінізації нервових волокон. Враховуючи, що наявність таких органел властива для білої речовини дефінітиву мозку, вважаємо, що цей процес мієлінізації має перманентний характер, тобто він забезпечує безперервне оновлення нервових оболонок протягом усього життя. Окрім того, суттєвим компонентом їх цитоплазми є мікротрубочки, які подібні до таких же нервових клітин. Через велику кількість мікротрубочок у відростках олігодендроцитів їх буває важко відрізнити від дендриту нервових клітин. I якщо розглядати таку клітину окремо, то їі помил- 
ково можна прийняти за нервову. Добре відомо, що відростки цих клітин, маючи пластинчату форму, $є$ відносно нечисленними в порівнянні з іншим типом гліальних елементів у білій речовині - фібрилярними астроцитами, які прямого відношення до нервових волокон не мають. Але, будучи тісно пов'язаними 3 кровоносними мікросудинами, вони організаційно співвідносяться з інтерфасцикулярними олігодендроцитами.

Отже, використовуючи шліфи пластинованих в епоксидній смолі неосмованих та осмованих тканин мозолистого тіла дорослих людей, ми отримали загальне уявлення про внутрішню структурну впорядкованість його взаємовідносин між різнохарактерними за функціональним призначенням тканинними компонентами.

Висновки. Встановлено, що у загальній масі мієлінізованих нервових волокон фасцикулярних порціонів у кластерному порядку розосереджені численні, чітко обмежені комірки, у яких містяться (у кожній по одному) інтерфасцикулярні олігодендроцити, що асоціюються 3 окремими субфасцикулярними сукупностями нервових провідників.

Принципово важливим положенням вважаємо те, що інтерстиційні прошарки в мозолистому тілі у своїй сукупності є складною тривимірною мережею, конструкція якої, будучи одночасно мережеподібною системою, що здійснює позасудинну циркуляцію рідини з розчиненими в ній поживними речовинами, яка омиває окремі субфасцикулярні порціоні, підпорядкована характеру розгалуження кровоносних мікросудин капілярного типу.

\section{Література:}

1. Боягина О. Д. Иерархические уровни морфологической организации нервных волокон в мозолистом теле человека. Morphologia. 2017. T. 11, № 2. C. 7-11.

2. Куприянов В. В. Микроциркуляторное русло / В. В. Куприянов, Я. Л. Караганов, В. И. Козлов. Москва, 1975. 172 с. 